\title{
The Application of E-Learning in the Didactic Process at the Faculty of Management in Czestochowa University of Technology: Organization, Tools, Model
}

\author{
Dorota Jelonek, Adam Nowicki, and Leszek Ziora \\ Czestochowa University of Technology, Czestochowa, Poland \\ jelonek@zim.pcz.pl,nowicki@zim.pcz.pl, ziora@zim.pcz.pl
}

\begin{abstract}
The paper puts emphasis on the application of e-learning at the Faculty of Management, Czestochowa University of Technology, Poland. The concept of e-learning at the Faculty of Management of Czestochowa University of Technology was presented since its development in 2011. There were presented organizational foundations of the OKO PCz Distance Education Centre with its organization design. The procedure of course creation, development, and implementation was also depicted with such phases as declaration of e-learning course preparation, the course project, multimedia recording of the course, implementation, and evaluation. The elearning platform tools with division into resources and activities, such as discussion board, surveys, workshop, lesson, and wiki, that are used in the process of education were showed. The three layer model of e-learning applied in the mentioned university was presented showing management, organizational, and technological tiers. There were presented statistical data concerning didactic hours realized in e-learning form and involving intramural and extramural studies. The development process of e-learning in Czestochowa University of Technology was presented with special focus on video studio availability.
\end{abstract}

Keywords: e-learning, moodle platform, didactic process, distance learning, multimedia

\section{Introduction}

Nowadays e-learning solutions are used all over the world by many different organizations and institutions including colleges, universities and so on. There exist many advantages of its application among which are worth mentioning: improvement of the whole didactic process, increase of its efficiency and efficacy, convenience for both tutors and students. The aim of this paper is to present the application of e-learning in Czestochowa University of Technology and especially in

Material published as part of this publication, either on-line or in print, is copyrighted by the Informing Science Institute. Permission to make digital or paper copy of part or all of these works for personal or classroom use is granted without fee provided that the copies are not made or distributed for profit or commercial advantage AND that copies 1) bear this notice in full and 2) give the full citation on the first page. It is permissible to abstract these works so long as credit is given. To copy in all other cases or to republish or to post on a server or to redistribute to lists requires specific permission and payment of a fee. Contact Publisher@,InformingScience.org to request redistribution permission. the Faculty of Management located in Poland. The article puts emphasis on such aspects as the concept of e-learning in mentioned university, its organization process together with "OKO Unit" (Distance Education Center), the process of courses preparation, applied tools, platform and what is the most significant the model of e-learning application in the didactic process. 
E-learning term embraces the whole of processes connected with teaching and learning in the environment and with the use of modern information technologies especially the Internet (Tadeusiewicz, 2005, p.4). E-learning appeared at the beginning of 90-ties of XX century and is constantly developed both in traditional e-learning form, hybrid training which is blended learning, m-learning (mobile learning) (Keegan, 2002), g-learning (game learning) and b-learning (bloglearning). Mobile learning (m-learning) is defined as the delivery of training by means of mobile devices such as mobile phones, PDAs and digital audio players, as well as digital cameras and voice recorders, pen scanners, etc. Model g-learning was considered by Schwabe and Göth, who describe the design of the MobileGame prototype, exploring the opportunities to support learning through an orientation game in a university setting (Schwabe \& Goth, 2005, p. 204-216).

The potential of blogs as learning spaces for students in the higher education sector was presented by Williams and Jacobs (2004, p. 232-247). They proved that blogs have the potential, at least, to be a truly transformational technology in that they provide students with a high level of autonomy while simultaneously providing opportunity for greater interaction with peers (Williams \& Jacobs, 2004, p. 232-247).

E-learning has been widely used for university-based and enterprise-based education. It is gaining applicability as an educational tool for a cost savings, institution reusability, its ability to enable students to study without the constraints of time and space and learner flexibility. In the literature of subject there is still ongoing discussion over advantages, disadvantages, quality, improvement of technical solutions, efficiency of e-learning application. In the discussion participate such experts from different domains as: education, computer science, information systems, psychology, sociology and educational technology, due to the fact that only multidimensional perception of elearning can ensure success of such ventures.

\section{The Concept of E-Learning in the Czestochowa University of Technology}

The first successful attempt of e-learning implementation in the educational process at the Czestochowa University of Technology was undertaken in 2001 at the Faculty of Mechanical Engineering and Computer Science. On-line courses were taught facultatively, i.e. students who submitted written agreement, participated in courses organized in such a form. In parallel the same courses were carried out extramurally. E-learning courses were led by teachers with a passion and for small groups of students. The dynamic development of e-learning in the Czestochowa University of Technology began in 2008 year as the effect of project realization entitled "the Development plan of the Czestochowa University of Technology" financed with the support from European Social Fund. In the project the e-learning was constituted by separate module (III). As a result of this module realization there were started both the server and the DELTA platform for the purpose of on-line courses realization based on Moodle platform in the 1.9.8 version (www.e-learning.pcz.pl). There were also prepared appropriate course patterns and innovative IT solutions including the Internet System supporting authors of e-learning courses within the range of course creations and preparation of the documentation which certainly contributed to the facilitation of activities connected with preparation and implementation of elearning courses.

Since that time the platform helps in development of e-education in Czestochowa University of Technology and is fully accepted working environment for students and teachers, helpful in the study and conveying knowledge with the usage of multimedia technologies.

Part of didactic activities for students of Czestochowa University of Technology is being realized in e-learning form that is with the use of methods and techniques of distance learning. E-learning is a form of teaching supporting traditional approach towards teaching which is realized with the 
help of Internet communication tools (such as e-mail, the discussion forum, chat, messenger, the internet telephony, videoconference). Advantages of lessons conducted in e-learning form it is first of all the possibility of its realization in the convenient time and place (with an access to the Internet). Such lessons base on efficient interaction realized on the lecturer-student interaction and has individual and multimedia character. Used in the Czestochowa University of Technology e-learning internet platform is a connection of the community service and a tool used in efficient teaching. It is worth mentioning that the educational offer of the Czestochowa University of Technology embracing e-learning lessons is systematically extended.

\section{Organizational Foundations of the Distance Education Center of Czestochowa University of Technology}

In the organizational structure of the Czestochowa University of Technology in the year 2010 was created organizational unit which deals with e-learning. This is called the OKO-PCz Distance Education Center of Czestochowa University of Technology. In Figure 1 is presented the organization design of OKO-PCz Distance Learning Center of Czestochowa University of Technology.

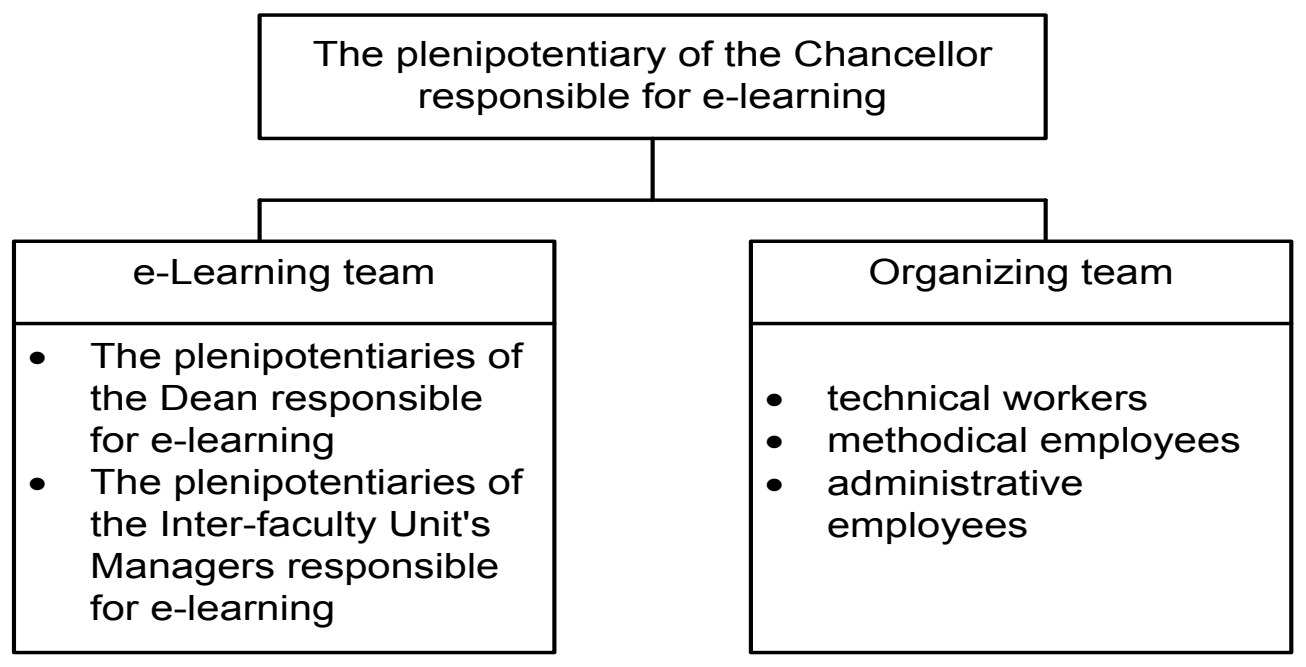

Figure 1. The organization design of the Center of Distance Education in the Czestochowa University of Technology

The structure of Distance education Center embraces the Plenipotentiary of the Chancellor responsible for e-learning, the team responsible for e-learning, which is comprised of Plenipotentiaries of Deans responsible for e-learning and Plenipotentiaries of Unit Managers responsible for e-learning as well as technical, methodical and administrative employees.

Duties of the Plenipotentiary of the Chancellor involve:

a) preparation and realization of university's e-learning development strategy,

b) performance of supervision over organization of trainings in the scope of e-learning for authors of courses as well as leading and performing e-learning courses,

c) performance of supervision over elaboration of admission rules for courses which are to be used during e-learning teaching,

d) management of teams' works, 
e) performance of supervision over works connected with e-learning of technical, methodical and administrative employees,

f) the settlement with a teams' cooperation of work schedules connected with e-learning for a given academic year.

The e-learning team comprises of representatives from six Faculties:

1. The Faculty of Constructions

2. The Electric Faculty

3. The Faculty of Mechanical Engineering and Computer Science

4. The Faculty of Environmental Engineering and Biotechnology

5. The Faculty of Process, Materials Engineering and Applied Physics

6. The Faculty of Management

Representatives of Interdivisional Units are also present and include:

1. The study of Foreign Languages

2. The interdivisional Study for Teachers Training

Every member of the e-learning team performs the function of e-learning coordinator within the framework of the Faculty or the Unit. The duties of the team member involve undertaking and coordinating all activities aiming at appropriate usage of e-learning in didactic processes realized on every Faculty. The team worked out the regulations of carrying out e-learning courses and detailed rules of e-learning courses creation and implementation in Czestochowa University of Technology. Taking care for high quality of e-learning courses it was stated that the courses are prepared by persons having suitable preparation confirmed with the diploma of training completion.

By now two trainings for employees of Czestochowa University of Technology were organised entitled "e-teaching in practice of the university" tutored by experts from external trainings company. The first training was finished in March of the year 2011 and 120 persons participated in it. The second training for 80 persons was finished in June 2011. Every participant within the framework of 28 hours of training acquired practical skills from the range of e-learning courses preparation and ways of e-learning platform operation. Participants of the training were familiarized with e-learning from the position of e-learning student, what can additionally help them in outlining individual and effective vision of e-learning.

The aim of trainings was to give complete answers to the questions:

What is e-learning used for?

How to create e-learning courses?

How to operate the platform?

How to teach?

How to receive credit?

How to initiate and encourage students to the use of platform?

Participants highly evaluated essential values of the training and the preparation and didactic skills of experts leading the course. Participants who finished the training with the positive mark received certificates authorizing to conduct e-learning courses in Czestochowa University of Technology. The team responsible for e-learning defined in a separate document detailed rules of 
creation and implementation of e-learning courses and it was entitled "Rules of creation and implementation of e-learning courses in Czestochowa University of Technology". In accordance with these regulations the legal and meritorical responsibility lies on the author. However over obeying rules by the author concerning preparation and implementation of courses is a control from the side of member of the team (the Plenipotentiary of Dean of appropriate Faculty). The member of the team has a right not to permit the course to be implemented and included in the educational offer of the Faculty or the Unit, if it does not fulfil rules of preparation and implementation of courses.

The procedure of e-learning course preparation and realization in Czestochowa University of Technology is presented in Figure 2.

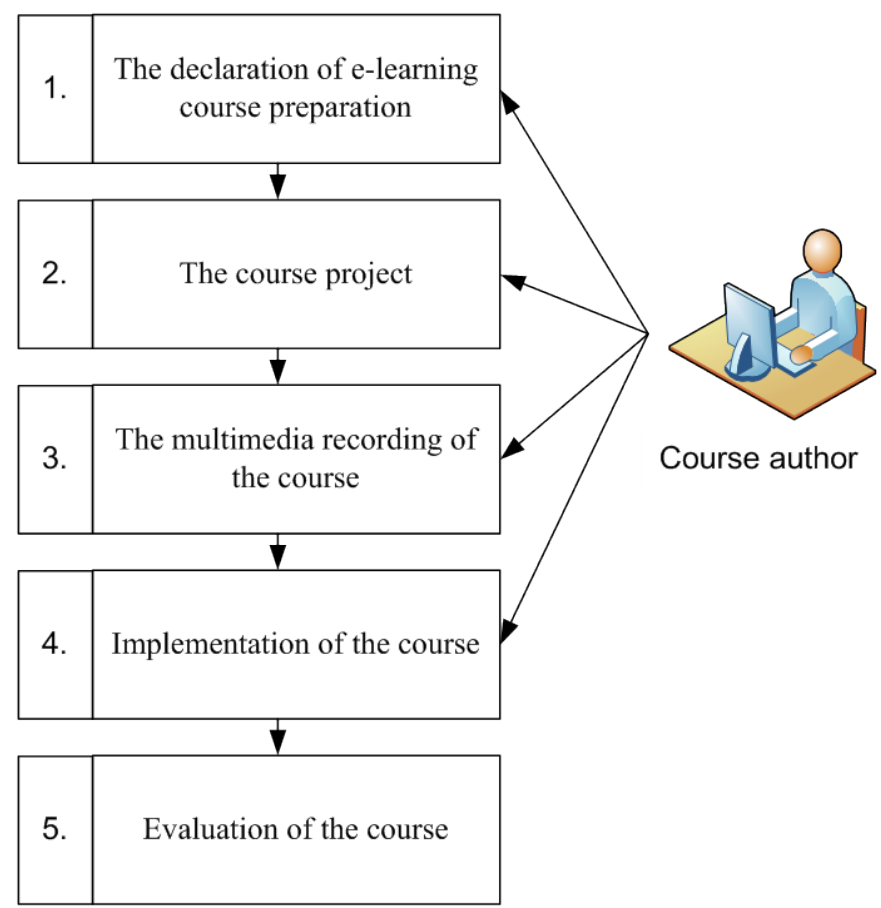

Figure 2. The procedure of e-learning course preparation and implementation in Czestochowa University of Technology

The procedure of e-learning course preparation and implementation in Czestochowa University of Technology consists of five stages.

The first stage: The declaration of e-learning course preparation is an official proposal of the author, directed to the Dean of the Faculty or the manager of the unit. It is a guarantee for both sides that prepared course will be a part of educational offer in a specific time.

The second stage: The course project includes most of all the list of component problems of the course (both e-learning part and conducted in a traditional method) and so called knowledge card (what the student must know) and interaction (what methods should be used to gain knowledge?). For every problem there is one card of knowledge and one card of interaction assigned.

This stage of course preparation is finished by meritorical assessment of course content made by direct superior. Only positive result of assessment allows for its implementation on the platform.

The third stage: The multimedia recording of the course on e-learning platform created in the exact compliance with the course program. 
After finishing the phase of implementation the course undergoes technical control conducted by Dean's plenipotentiary. The correctness of platform tools utilization is also evaluated e.g. creation of quizzes, discussion forums, tests etc. When the assessment is positive the course is then made available for the students.

The fourth stage: Realization of the course. Students' participation in e-learning courses. Constant control of learning progress. Partial grades and final grade for every student.

The fifth stage: After finishing the course it is marked by its participants with the use of course evaluation system which is available on-line. Conducted courses obtain comparatively high marks. The average mark of courses realized in academic year 2012/2013 was 4,3 in the fourdegree scale 2-lowest mark, 5 the highest mark. Formalization of preparation, implementation and realization rules of e-learning courses and control of effects on every stage assure the good quality of proposed courses

\section{E-learning tools in Czestochowa University of Technology}

In the Czestochowa University of Technology the Moodle platform is used for the purpose of elearning courses realization. The name Moodle is an acronym Modular Object-Oriented Dynamic Learning Environment, this is the application package intended to the creation of Internet courses used in distance education. This software is available free of charge according to the public GNU licence. Moodle base on PHP and works in with many databases, particularly with MySQL. Moodle has a modular design, which allows for simple addition of course components. In Poland above 1042 institutes registered Moodle, and on the list can be found not only institutions connected with education. These are, for example, schools of all levels, colleges, universities, government agencies, business and commercial institutions, hospitals, libraries, offices and employment agencies. Preparing e-learning course on Moodle platform the teacher has a selection of wide range of possibilities which are offered by the system such as: surveys, quizzes, dictionaries, lessons, workshops, wiki, chat, forum, registry, file directory, dialogue, evaluation, questionnaires and voting. Every course created with the utilization of Moodle platform may consists of two basic kinds of objects, i.e., resources and activities. Resources are objects which allow placing the various content in the course, making the equivalent of traditional didactic materials. There can be also used interactive elements engaging students in the process of learning applying activities such as e.g. the assignment, survey, forum, lessons, quizzes, workshops.

There exist 14 different types of activities in the standard Moodle platform.

- $\quad$ "the assignment module allows teachers to collect work from students, review it and provide feedback including grades". It is possible to submit different types of files such as text, spreadsheets, images, audio or video files and time limit of a given task's provision may be set

- the chat module allows for discussions among students and teacher in a real time

- a choice activity allows the teacher to ask a question and gives the students possibility to choose one answer among other ones

- the database module "allows the teacher and/or students to build, display and search a bank of record entries about any conceivable topic" [source: Moodle documentation: http://docs.moodle.org/26/en/Activities]

- the external tool enables Moodle users to interact with other resources places on different websites 
- the feedback module allows for creation and carrying out surveys in order to collect feedback

- the forum module is "an activity where students and teachers can exchange ideas by posting comments" [source: Moodle documentation]

- the glossary module "allows participants to create and maintain a list of definitions, like a dictionary" [source: Moodle documentation]

- the lesson module "presents a series of HTML pages to the student who is usually asked to make some sort of choice underneath the content area". There exist two basic lesson page types: question pages and content pages [source: Moodle documentation]

- the quiz module "allows the teacher to design and build quizzes consisting of a large variety of question types including multiple choice, true-false, and short answer questions" [source: Moodle documentation]

- SCORM (Sharable Content Object Reference Model) "is a collection of specifications that enable interoperability, accessibility and reusability of web-based learning content" [source: Moodle documentation]

- the survey module is a "course activity that provides a number of verified survey instruments, including COLLES (Constructivist On-Line Learning Environment Survey) and ATTLS (Attitudes to Thinking and Learning Survey)",

- a wiki is a "collection of collaboratively authored web documents". It allows students for creation of a content connected to the topic of specific lesson [source: Moodle documentation]

- $\quad$ workshop is a "peer assessment activity with many options". It allows for submitting students' work using online text tool and attachments.

The example of microeconomics course outline for the public health field of study at the Faculty of Management is presented in Figure 3. 


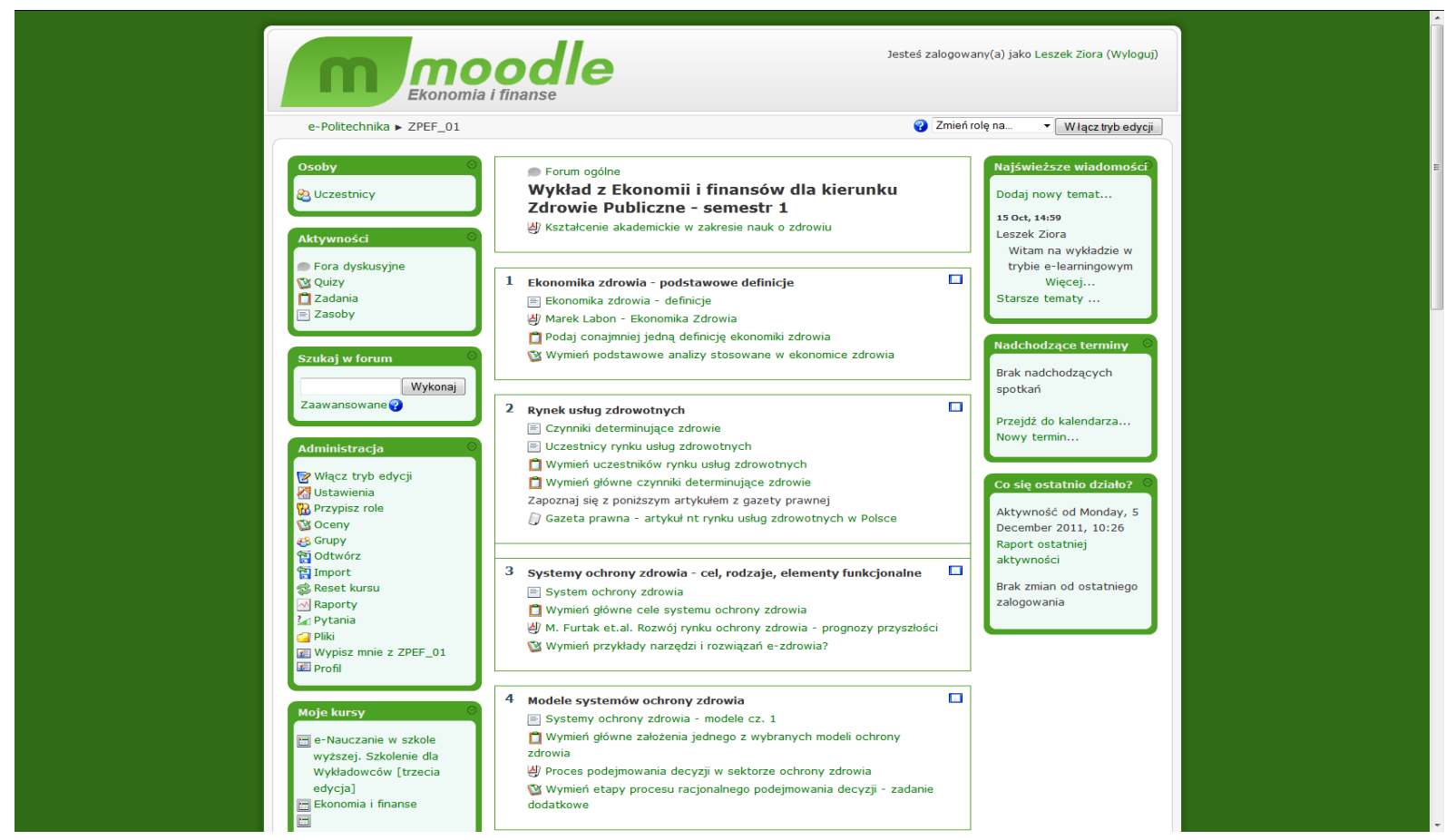

Figure 3. Economics and Finances Moodle course outline at the Faculty of Management Source: Authors' own study

\section{E-learning Model in the Czestochowa University of Technology}

The E-learning model in Czestochowa University of Technology is built with three layers: the management, organizational, technological. (See Figure 4.)

In "the management" layer the most important part is fulfilled by the Plenipotentiary of the Chancellor responsible for e-learning who manages all works connected with e-learning in

Czestochowa University of Technology. The PCz Chancellor supervises works of the plenipotentiary and of the team responsible for e-learning. The team responsible for e-learning consists of plenipotentiaries of Deans and Managers of Interdivisional Units. In the faculties correct realization of e-learning teaching is supervised by plenipotentiaries of Deans or Managers of Interdivisional Units. For the whole of didactic process, and for e-learning didactics as well is responsible the Dean of every Faculty.

In the "organization" layer there were specified rules of placing courses on the OKO $\mathrm{PCz}$ platform. The employees who possess the certificate of e-learning course completion are able to place prepared and confirmed courses to common for all faculties e-learning platform. The system administrator supervises failure-free operation of e-learning server.

The "technological" layer is built with the utilization of Moodle platform tools. The didactic process can be supported with the usage of SCROM and external modules such as quizzes and hotpotatoes, discussion forums and chats. Teachers can create interactive lesson units and blogs. There are also available solutions for concreating Wikipedia by addition and edition of entries by students. There is a possibility to place Power Point presentations as well. 


\section{MANAGEMENT LAYER}

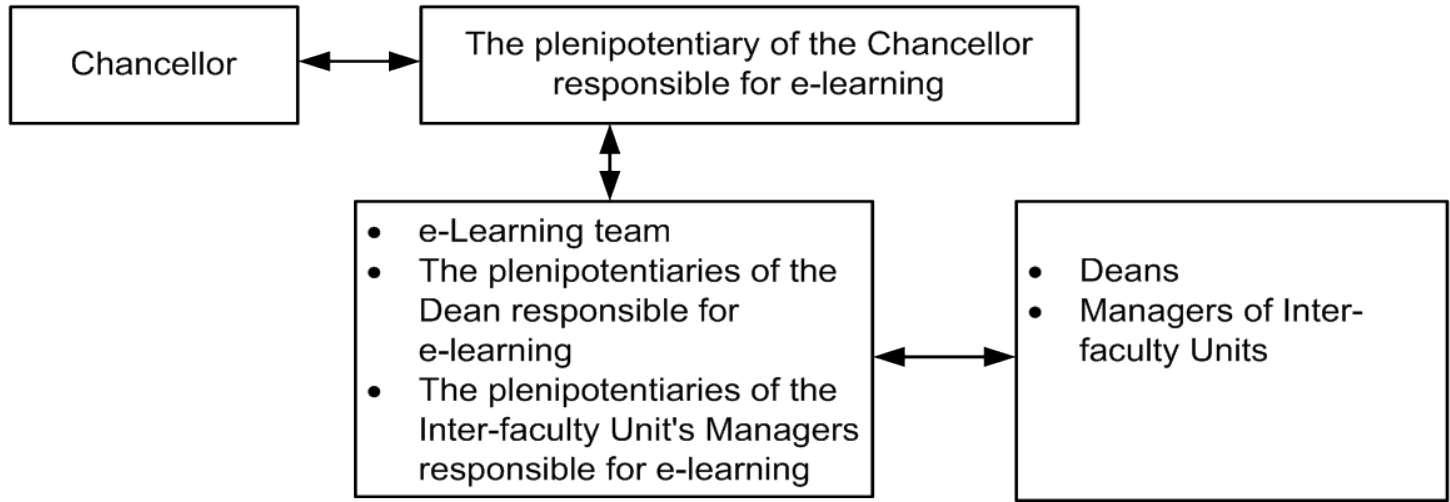

\section{ORGANIZATIONAL LAYER}

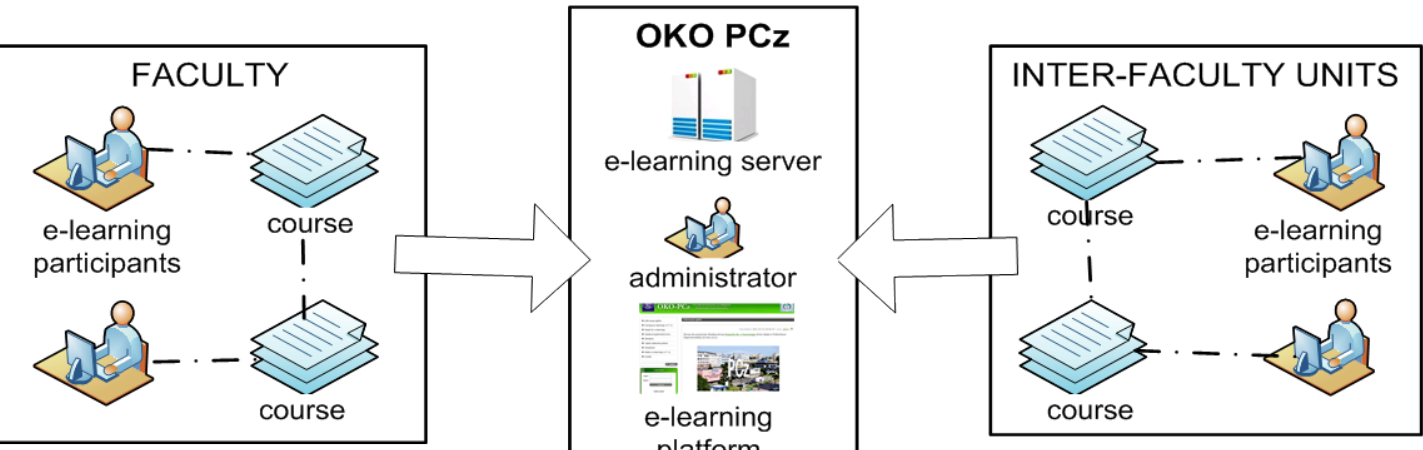

TECHNOLOGICAL LAYER

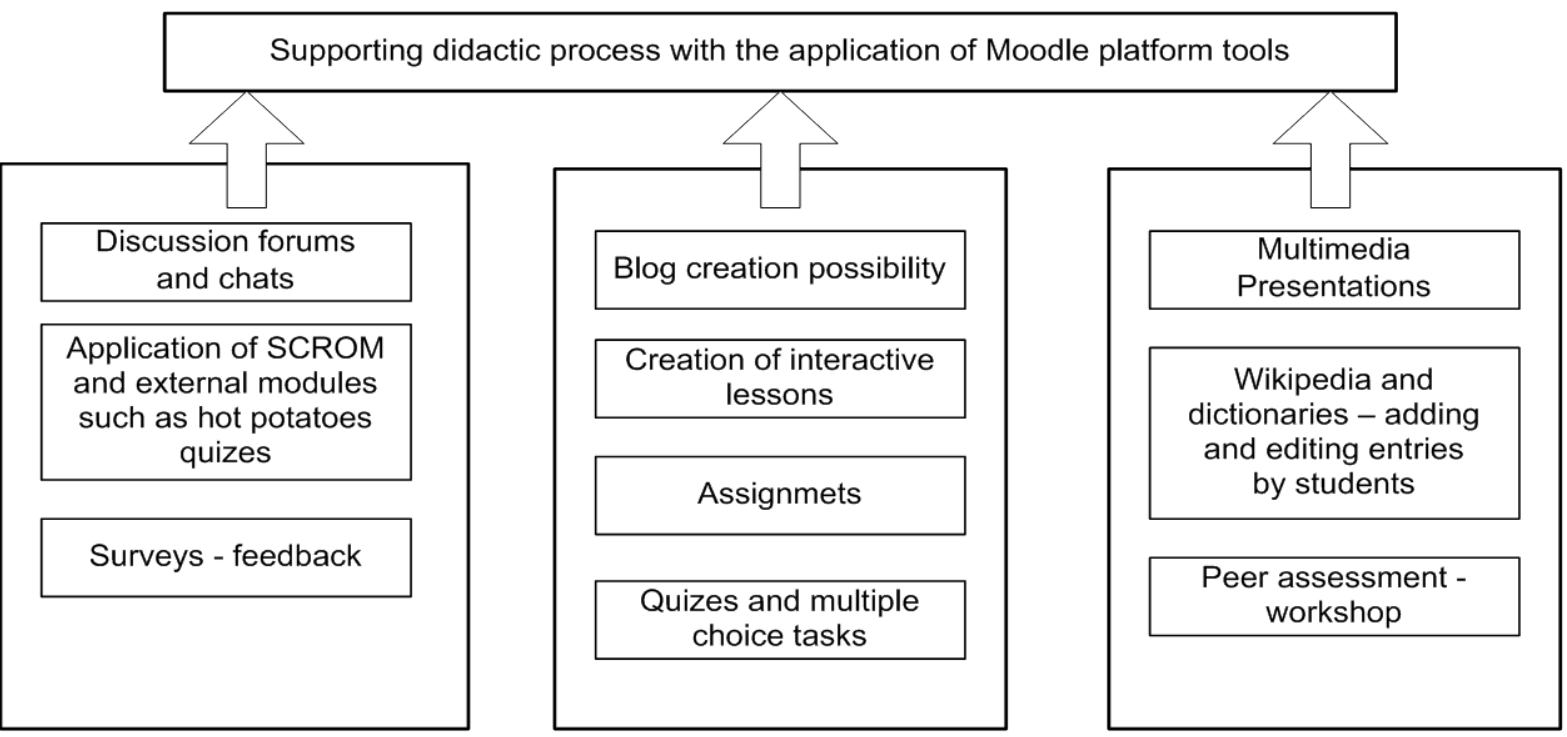

Figure 4. E-learning model in Czestochowa University of Technology Source: Authors' own study 


\section{E-learning at the Faculty of Management}

The Faculty of Management of Czestochowa University of Technology has been offering elearning courses since 2011 year. E-learning platform is a part of OKO Centre of Distance Education. The number of subjects being realized in e-learning mode in years 2011/2012 and $2012 / 2013$ is minimal. This results not only in absence of interests of teachers with this form of teaching but also with legislations. In compliance with the government order of the Minister of Science and Higher Education dated 25 September 2007, paragraph 5 states that "the number of didactic hours on intramural studies and nonstationary, conducted with the use of distant learning methods and technologies cannot be greater than $60 \%$ of aggregated hours determined in standards of education for particular fields of studies and levels of education except for practical and laboratory subjects". Unfortunately, the University's senate resolutions limited the number of didactic hours which could be realized in e-learning form. At first it was 60 hours in the academic year at a particular field of study and in the following year it was extended to 180 hours for a field of study. Only since the academic year 2013/2014 the internal limitations were cancelled and the 2007 Minister's Resolution is in force. The statistical data analysis contained in Table 1 allows drawing out the following conclusions:

1. The participation of e-learning hours realized in particular fields of studies fluctuates from $0,4 \%$ to $4,2 \%$ of all didactic hours on a given field of studies in the academic year $2013 / 2014$.

2. The perspective of achievement admissible number of e-learning hours that is $60 \%$ of aggregated number of hours realized on a given field of studies seems to be great challenge for nearest several years.

Table 1. Percentage share of e-learning hours in relation to all didactic hours realized in a given field of studies in years 2011/2012, 2012/2013, 2013/2014

Source: Authors' own study

\begin{tabular}{|c|c|c|c|c|c|c|c|c|c|}
\hline \multirow[b]{3}{*}{$\begin{array}{l}\text { Field of } \\
\text { studies }\end{array}$} & \multicolumn{9}{|c|}{ Academic year } \\
\hline & \multicolumn{3}{|c|}{$2011 / 2012$} & \multicolumn{3}{|c|}{$2012 / 2013$} & \multicolumn{3}{|c|}{$2013 / 2014$} \\
\hline & $\begin{array}{l}\text { Num } \\
\text { ber } \\
\text { of e- } \\
\text { learn } \\
\text { ing } \\
\text { hours }\end{array}$ & $\begin{array}{l}\text { Num- } \\
\text { ber of } \\
\text { hours } \\
\text { in a } \\
\text { field } \\
\text { of } \\
\text { studies }\end{array}$ & $\begin{array}{l}\text { E- } \\
\text { learning } \\
\text { share in } \\
\text { hours in } \\
\text { the field } \\
\text { of study }\end{array}$ & $\begin{array}{l}\text { The } \\
\text { num- } \\
\text { ber of } \\
\text { e- } \\
\text { learn- } \\
\text { ing } \\
\text { hours }\end{array}$ & $\begin{array}{l}\text { Num- } \\
\text { ber of } \\
\text { hours } \\
\text { in a } \\
\text { field of } \\
\text { studies }\end{array}$ & $\begin{array}{l}\text { E- } \\
\text { learn- } \\
\text { ing } \\
\text { share in } \\
\text { hours } \\
\text { in the } \\
\text { field of } \\
\text { study }\end{array}$ & $\begin{array}{l}\text { The } \\
\text { num- } \\
\text { ber of } \\
\text { e- } \\
\text { learn- } \\
\text { ing } \\
\text { hours }\end{array}$ & $\begin{array}{l}\text { Num- } \\
\text { ber of } \\
\text { hours } \\
\text { in a } \\
\text { field of } \\
\text { studies }\end{array}$ & $\begin{array}{l}\text { E-learning } \\
\text { share in } \\
\text { hours in } \\
\text { the field of } \\
\text { study }\end{array}$ \\
\hline $\begin{array}{l}\text { Man- } \\
\text { agement }\end{array}$ & 48 & 3055 & $1,6 \%$ & 65 & 2910 & $2,2 \%$ & 91 & 2910 & $3,1 \%$ \\
\hline $\begin{array}{l}\text { Man- } \\
\text { agement } \\
\text { and Pro- } \\
\text { duction } \\
\text { Engi- } \\
\text { neering }\end{array}$ & 24 & 3300 & $0,7 \%$ & 106 & 3300 & $3,2 \%$ & 127 & 3300 & $3,8 \%$ \\
\hline
\end{tabular}




\begin{tabular}{|l|l|l|l|l|l|l|l|l|l|}
\hline $\begin{array}{l}\text { Infor- } \\
\text { matics } \\
\text { and } \\
\begin{array}{l}\text { Econo- } \\
\text { metrics }\end{array}\end{array}$ & 24 & 2010 & $1,2 \%$ & & 2010 & $0,6 \%$ & 28 & 2010 & $1,4 \%$ \\
\hline Logistics & & 2910 & $0,0 \%$ & 84 & 2910 & $2,9 \%$ & 123 & 2910 & $4,2 \%$ \\
\hline $\begin{array}{l}\text { Public } \\
\text { Health }\end{array}$ & 12 & 2640 & $0,5 \%$ & 22 & 2610 & $0,8 \%$ & 22 & 2610 & $0,8 \%$ \\
\hline $\begin{array}{l}\text { Work } \\
\text { safety }\end{array}$ & \multicolumn{2}{|l|}{ Started 1.10 .2012} & 9 & 2505 & $0,4 \%$ & 9 & 2505 & $0,4 \%$ \\
\hline Total: & $\mathbf{1 0 8}$ & & & $\mathbf{2 8 9}$ & & & $\mathbf{4 0 0}$ & & \\
\hline
\end{tabular}

In Table 2 is presented juxtaposition of didactic hours realized in e-learning form on intramural and extramural studies in years 2011/2012,2012/2013, 2013/2014

Table 2: Juxtaposition of didactic hours realized in e-learning form on intramural and extramural studies in years 2011/2012, 2012/2013, 2013/2014 Source: Authors' own study

\begin{tabular}{|c|c|c|c|}
\hline \multirow{3}{*}{ Form of studies } & \multicolumn{3}{|c|}{ Academic year } \\
\hline & 2011/2012 & 2012/2013 & $2013 / 2014$ \\
\hline & \multicolumn{3}{|c|}{ Number of e-learning hours } \\
\hline Intramural studies & 108 & 117 & 271 \\
\hline Extramural studies & 0 & 172 & 129 \\
\hline Total: & 108 & 289 & 400 \\
\hline
\end{tabular}

The analysis of composition list allows from one hand optimistically prognosing the growth of general number of subjects realized in e-learning form, on the other hand in current academic year there was a decrease in quantity of subjects which are (or they will be realized in the summer term) realized on extramural studies, and especially for such students it is the most desirable form of learning. The offer of e-learning subjects on extramural studies will help to diminish the number of Saturday-Sunday meetings which take place at the Faculty of Management for nonstationary studies, and this consequently will help students to save costs of commuting and night's lodging. The influence on the fall of the quantity of e-learning hours on extramural studies has undoubtedly a decrease of the general number of students on extramural studies and the fact, that in 2013/2014 year due to small number of candidates were not started four directions of studies from the offer of the Faculty of Management. Unfortunately deepening in Poland the population decline and progressive economic crisis will cause the further decrease of the number of students on extramural studies which are payable studies. 


\section{The Development of E-Learning in Czestochowa University of Technology}

Development plan of e-learning in Czestochowa University of Technology concerns executions in the nearest time of two trainings for employees.

The first training was for employees who never conducted e-learning courses and want to use in practice this form of educational activities. The positive credit reception is a condition to obtainment of the certificate and to realization of didactic courses on OKO platform. The greater number of teachers authorized to the realization of e-learning lessons should effect in increase of the number of lessons realized in e-learning form.

In the second training will participate employees who already conduct e-learning courses. The aim of the training is development of teachers' skills in the scope of:

- $\quad$ Graphics processing

- $\quad$ Using open educational resources on the Internet

- $\quad$ The deposition of multimedia elements from other platforms,

- $\quad$ The creation of podcasts, screencasts, own video sequences

- $\quad$ Adapting created services for mobile devices

The Czestochowa University of Technology has at its disposal good base for the purpose of own video sequences creation. From 2012 in the Czestochowa University of Technology functions PLATON platform aimed at science service. Two from among many modern services of the PLATON platform can be used in e-learning organization. They include:

- $\quad$ HD videoconferences

- $\quad$ HD scientific television

The presentation of the local studio of U5 television of the Czestochowa University of Technology is presented in Figure 5.
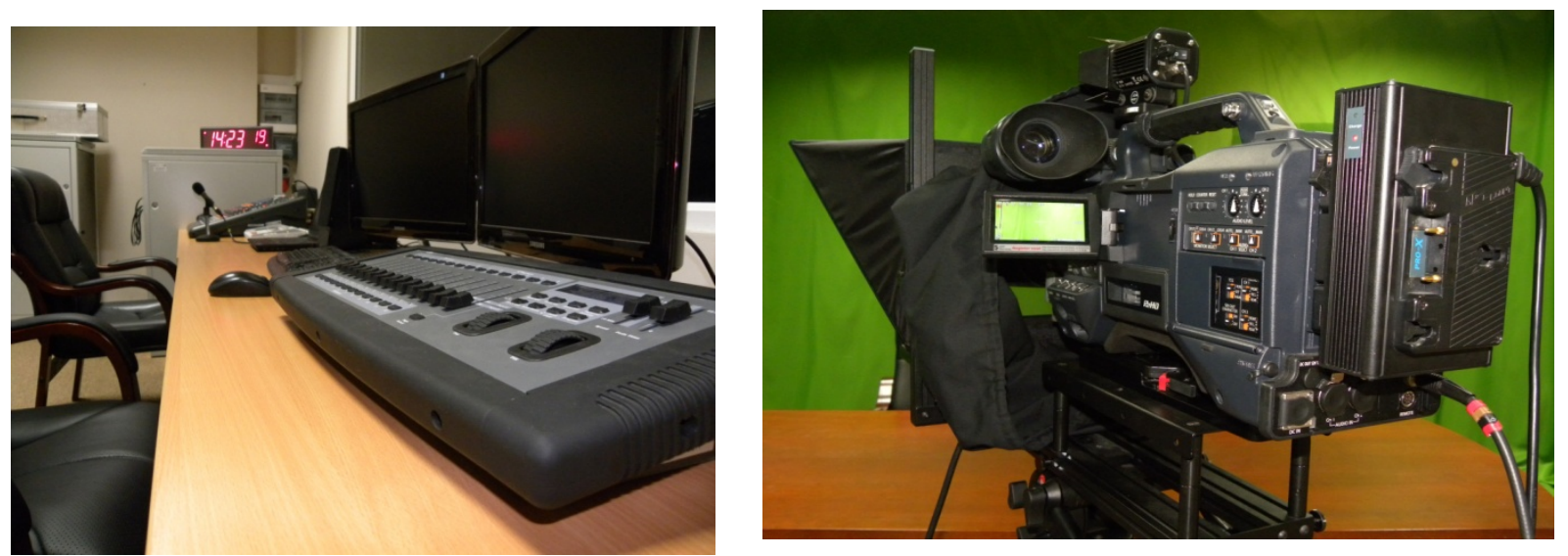

Figure 5. Studios of the scientific HD television in Czestochowa University of Technology

The e-learning model in Czestochowa University of Technology was meticulously elaborated within the framework of OKO-PCz team, and refers to the best standards in the scope of distance education. The development of Information Technologies and ideas notified by teachers are inspi- 
ration to the continuous improvement and changes in the e-learning model in Czestochowa University of Technology.

\section{Conclusions}

E-learning is sometimes identified with placing within the framework of platform less or more polished up presentations, and on its basis students can prepare themselves to receive credit for subject. In the Czestochowa University of Technology such approach is considered as unacceptable, because during lesson progress the key-matter is interaction with students. Such an approach will assure the maintenance of proper level of education and will become in effect a source of the satisfaction both for lecturers and students.

The research results of the survey entitled "The future of e-learning" (https://oko.pcz.pl) encourage to realization of activities on developing e-learning in Czestochowa University of Technology where the option "Useful and I would like to use it" was selected by 512 students, and the option "Useful, but I do not want to use it" was selected by 19 students" and the option "It is not useful" by 94 students. Moreover the students highly assess e-learning courses in which they took part in. The positive result gave the answers to the question of the information service of the platform, mainly whether it is useful, understandable and includes all of the necessary information. $62 \%$ of the students said "rather yes" and $11 \%$ marked "definitely yes". The university and the people engaged in the platform make a lot of effort to prepare the portal well for the students allowing them get the necessary information ably and quickly (Terlicka, 2013, p. 182-185).

Cited above research results confirmed huge interest of teachers in this form of teaching and their conviction concerning e-learning efficiency in academic teaching. More than half of the academic teachers, i.e., $60 \%$, is of the opinion that the e-learning improves the image of the university - it is seen more as a modern one. They appreciate the fact that the use, diversity of the e-learning makes the university more attractive and it may lead to the increase of the number of students who would like to study at the Czestochowa University of Technology.

\section{References}

Ośrodek Kształcenia na Odległość Politechniki Częstochowskiej, http://www.oko.pcz.pl.

Platforma e-learningowa DELTA Politechniki Częstochowskiej http://www.e-learning.pcz.pl/

Cpałka K., \& Ulfik A. (2011). Szkolenia i nowe narzędzia dla autorów kursów e-learningowych, Politechnika Częstochowska, 44, 14-15.

Keegan, D. (2002). The future of learning: From elearning to mlearning, Fern Universitat -Hagen, November 2002.

Rozporządzenie Ministra Nauki i Szkolnictwa Wyższego z dnia 25 września 2007 r. w sprawie warunków, jakie musza być spełnione, aby zajęcia dydaktyczne na studiach mogły być prowadzone $\mathrm{z}$ wykorzystaniem metod i technik kształcenia na odległość. Dziennik Ustaw Nr 188.

Uchwała nr 281/2010/2011 Senatu Politechniki Częstochowskiej z dnia 29 czerwca 2011 w sprawie: zasad $\mathrm{i}$ trybu rozliczania pensum dydaktycznego i godzin ponad wymiarowych w roku akademicki $2011 / 2012$.

Uchwała nr 392/2011/2012 Senatu Politechniki Częstochowskiej z dnia 27 czerwca 2012 w sprawie: zasad $\mathrm{i}$ trybu rozliczania pensum dydaktycznego i godzin ponad wymiarowych w roku akademicki 2012/2013.

Schwabe, G., \& Göth, Ch. (2005) Mobile learning with a mobile game: Design and motivational effects. Journal of Computer Assisted Learning, 21(3), 204-216. 
Tadeusiewicz, R. (2005). E-learning szansq wzbogacenia oferty edukacyjnej Uczelni, Biuletyn Informacyjny Pracowników AGH, Nr 138, luty 2005, p.4

Terlicka, K. (2013). The e-learning use at the universities on the basis of Czestochowa University of Technology, W:Revue mladych vedcov. Stefan Hittmar a kolektiv. Zbornik vedeckych prac doktorandov a mladych vedeckych pracovnikov. EDIS, University Publishing House, University of Zilina, Zilina, 2013, p. 182-185.

Williams, J. B., \& Jacobs, J. (2004). Exploring the use of blogs as learning spaces in the higher education sector. Australasian Journal of Educational Technology, 20(2), 232-247.

\section{Biographies}

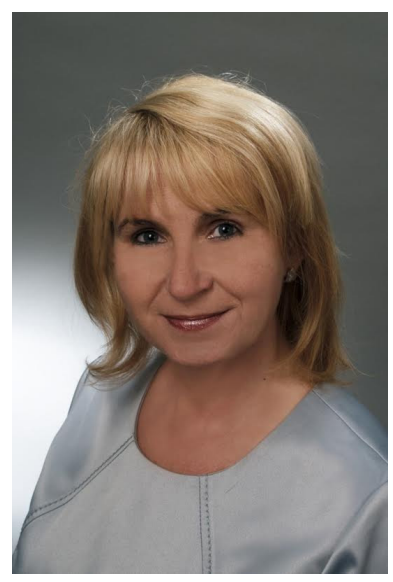

Dorota JELONEK is an associate Professor of Management at the Czestochowa University of Technology, Poland. Her research interests include management information systems, business and information processes, innovations including open innovations and e-business systems. She has more than 170 refereed publications as books, papers in conference proceedings and papers in jounals. Currently she performs a function of Vice Dean for Science of the Management Faculty and Chairman of e-learning team at Czestochowa University of Technology.

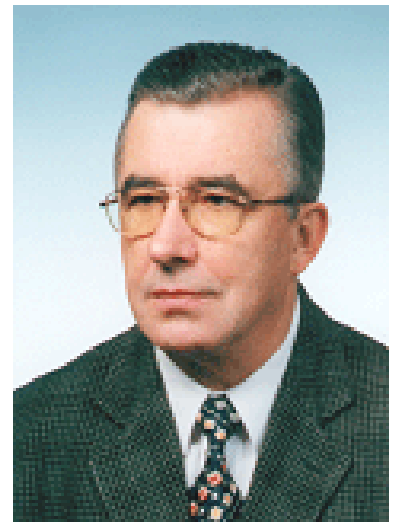

Adam NOWICKI many years' standing the position of the Director of Business Informatics Institute, Wroclaw University of Economics, Poland. He is currently the head of the Business Informatics Department at the Faculty of Management in Czestochowa University of Technology. He specializes in the issues of Management Information Systems' improvement. He is the author and editor of many academic course books from the field of Management Information Systems, Marketing and Logistics Information systems.

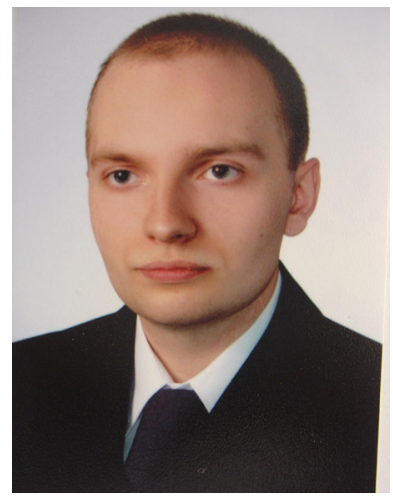

Leszek ZIORA Ph.D., employed as Assistant Professor at Czestochowa University of Technology, the Faculty of Management, Business Informatics Department. He is the author of over 30 papers published in domestic and international journals. His scientific interests include Business Intelligence systems, data security in computer networks, application of linguistics in the management. He is member of Scientific Association of Business Informatics and International Association of Engineers. 